\title{
Efektivitas Seed Coating dan Biopriming dengan Rizobakteri dalam Mempertahankan Viabilitas Benih Cabai dan Rizobakteri selama Penyimpanan
}

\author{
The Effectiveness of Seed Coating and Biopriming with Rhizobacteria on Viability of \\ Hot Pepper Seed and Rhizobacteria during Storage
}

Ita Madyasari ${ }^{1}$, Candra Budiman ${ }^{2}$, Syamsuddin $^{3}$, Dyah Manohara ${ }^{4}$, dan Satriyas Ilyas ${ }^{2 *}$

Diterima 08 Maret 2017/Disetujui 25 Oktober 2017

\begin{abstract}
The objective of the study was to obtain the best coating formula for hot pepper seeds, and evaluate the effect of seed coating and biopriming with rhizobacteria on viability of hot pepper seeds and rhizobacteria during storage. Experiment 1 was arranged in a completely randomized design with one factor i.e. 11 coating formula. Experiment 2 was arranged in a nested plot design with two factors, storage period $(0,4,8,12,16,20$, and 24 weeks) as main factor and seed treatment consisted of 11 treatments (control, seed coating with E1+F2B1, ST116B, CM8; biopriming $24 \mathrm{~h}$ with E1+F2B1, ST116B, CM8; biopriming $48 \mathrm{~h}$ with E1+F2B1, ST116B, and CM8; priming metalaxyl) as nested factor. Result of experiment 1 indicated that the best coating formula for hot pepper seed was sodium alginate 2.5\% and was used in experiment 2. Experiment 2 showed that seed coating and biopriming with rhizobacteria were able to maintain seed viability (79-89\%) for 24 weeks of storage at 27-30 ${ }^{\circ} \mathrm{C}$ as compared to priming metalaxyl (54\%). Biopriming E1+F2B1 $24 \mathrm{~h}$ or CM8 $48 \mathrm{~h}$ resulted in the highest index of seed vigor after 24 weeks of storage. Population of rhizobacteria in seed tissue decreased in bioprimed seeds from $10^{5}-10^{7}$ cfu $g^{-1}$ to $10^{4}$ cfu $g^{-1}$ after being stored for 24 weeks.
\end{abstract}

Keywords: rhizobacteria isolates, seed treatment, seed vigor, sodium alginate

\begin{abstract}
ABSTRAK
Penelitian ini bertujuan mendapatkan formula coating terbaik pada benih cabai dan mengevaluasi pengaruh seed coating dan biopriming dengan rizobakteri dalam mempertahankan viabilitas benih cabai dan rizobakteri selama penyimpanan. Percobaan 1 menggunakan rancangan acak lengkap satu faktor yang terdiri atas 11 formula coating. Percobaan 2 menggunakan rancangan petak tersarang dua faktor, periode simpan $(0,4,8,12,16$, 20, dan 24 minggu) sebagai faktor utama dan perlakuaan benih yang terdiri atas 11 perlakuan (kontrol, seed coating dengan E1+F2B1, ST116B, CM8; biopriming 24 jam dengan E1+F2B1, ST116B, CM8; biopriming 48 jam dengan E1+F2B1, ST116B, dan CM8; priming metalaksil) sebagai faktor tersarang. Hasil Percobaan 1 menunjukkan bahwa formula coating terbaik untuk benih cabai ialah natrium alginat $2.5 \%$ dan digunakan pada percobaan 2. Percobaan 2 menunjukkan bahwa seed coating dan biopriming dengan rizobakteri mampu mempertahankan viabilitas benih (78-89\%) selama 24 minggu penyimpanan pada suhu $27-30{ }^{\circ} \mathrm{C}$ dibandingkan priming metalaksil (54\%). Biopriming E1+F2B1 24 jam atau biopriming CM8 48 jam menghasilkan indeks vigor paling tinggi setelah disimpan selama 24 minggu. Populasi rizobakteri di dalam jaringan benih menurun pada benih yang diberi perlakuan biopriming dari $10^{5}-10^{7} \mathrm{cfu} \mathrm{g}^{-1}$ menjadi $10^{4} \mathrm{cfu} \mathrm{g}^{-1}$ setelah disimpan selama 24 minggu.
\end{abstract}

Kata kunci: isolat rizobakteri, natrium alginat, perlakuan benih, vigor

\footnotetext{
${ }^{1}$ Mahasiswa Program Studi Ilmu dan Teknologi Benih, Sekolah Pascasarjana, Institut Pertanian Bogor

${ }^{2}$ Departemen Agronomi dan Hortikultura, Fakultas Pertanian, Institut Pertanian Bogor

J1. Meranti, Kampus IPB Darmaga, Bogor 16680, Indonesia

${ }^{3}$ Departemen Agroekoteknologi Fakultas Pertanian, Universitas Syah Kuala,

Kampus Darussalam, Banda Aceh, Indonesia

${ }^{4}$ Balai Penelitian Tanaman Rempah dan Obat. J1 Tentara Pelajar No 3A Menteng Bogor Barat

email: satriyas252@gmail.com (*penulis korespondensi)
} 


\section{PENDAHULUAN}

Cabai merupakan salah satu komoditas hortikultura yang peranannya cukup penting sebagai bahan pangan dan bahan baku industri. Jumlah konsumsi cabai terus mengalami peningkatan sejalan dengan pertumbuhan penduduk Indonesia setiap tahun (Syukur et al., 2012). Produktivitas cabai pada tahun 2014 mencapai 14.28 ton ha $^{-1}$ (Kementan, 2014). Hal ini masih jauh di bawah potensi hasil yang berkisar 12-20 ton ha ${ }^{-1}$. Peningkatan produksi dapat dilakukan dengan cara penggunaan benih bermutu, dan pengendalian hama penyakit tanaman. Penggunaan benih bermutu merupakan kunci awal dalam menghasilkan tanaman yang sehat. Pengendalian hama dan penyakit tanaman di lapangan juga penting dalam proses produksi. Salah satu cara untuk menghasilkan benih bermutu dan pengendalian hama penyakit yang ramah lingkungan adalah penggunaan rizobakteri pada benih.

Perlakuan rizobakteri pada benih dapat dilakukan dengan cara seed coating dan seed priming. Seed coating ialah pelapisan benih dengan beberapa bahan seperti pestisida, unsur hara yang direkatkan oleh bahan pengikat dalam meningkatkan performa benih, dan bentuk asli benih tidak berubah (Copeland dan McDonald, 2001). Hasil penelitian Tefa (2015), menunjukkan perlakuan seed coating dengan natrium alginat+xantan gum dicampur dengan tiga isolat yaitu Actinomycetes, Bacillus dan Pseudomonas meningkatkan viabilitas dan kesehatan benih cabai selama periode simpan 5 bulan.

Seed priming ialah penyerapan air untuk menginisiasi awal perkecambahan tetapi tidak sampai radikula muncul kemudian diikuti dengan pengeringan (McDonald, 2000). Biopriming dengan rizobakteri Bacillus polymixa BG25 yang dicampur dengan Pseudomonas fluorescence PG01 dapat mengurangi kejadian penyakit antraknosa yang disebabkan oleh Colletotrichum capsici sebesar 53-72\%, meningkatkan pertumbuhan tanaman, produksi buah dan mutu benih yang dihasilkan (Ilyas et al., 2015). Biopriming dengan rizobakteri ST116B pada benih cabai dapat meningkatkan pertumbuhan tanaman dan berpotensi mengendalikan penyakit busuk phytophthora (Ibrahim et al., 2014). Studi selanjutnya membuktikan bahwa biopriming menggunakan isolat rizobakteri tunggal maupun kombinasi (CM8, ST116B, ST116B+CM8) nyata meningkatkan jumlah daun dan menurunkan kejadian busuk phytophthora pada tanaman cabai sebesar 5882\% (Rosadiah et al., 2015).

Kelemahan aplikasi rizobakteri pada benih ialah jumlah populasi rizobakteri akan menurun selama penyimpanan. Hal ini akan mempengaruhi kemampuan rizobakteri sebagai PGPR. Hapsari (2013) melaporkan, benih kedelai yang dilapisi dengan Methylobacterium spp. dan arabic gum yang disimpan selama 6 bulan pada suhu kamar mengalami penurunan populasi rizobakteri dari $10^{3}-10^{7} \mathrm{cfu} \mathrm{g}^{-1}$ menjadi $10^{1}-10^{2} \mathrm{cfu} \mathrm{g}^{-1}$, walaupun demikian daya berkecambahnya masih lebih tinggi dibandingkan dengan kontrol. Tujuan penelitian ini ialah mendapatkan formula coating terbaik untuk benih cabai dan mengevaluasi pengaruh seed coating atau biopriming dengan rizobakteri dalam mempertahankan viabilitas benih cabai dan rizobakteri selama penyimpanan.

\section{BAHAN DAN METODE}

Penelitian dilaksanakan di Laboratorium Hama dan Penyakit, Balai Penelitian Tanaman Rempah dan Obat Bogor; Laboratorium Ilmu dan Teknologi Benih, Departemen Agronomi dan Hortikultura, Fakultas Pertanian, Institut Pertanian Bogor pada bulan Februari sampai Desember 2016. Benih yang digunakan ialah benih cabai varietas Laris diperoleh dari PT East West Seed Indonesia yang dipanen pada tanggal 5 Oktober 2015. Benih diuji terlebih dahulu (3 Februari 2016) sebelum digunakan dalam percobaan, diperoleh daya berkecambah $88 \%$ dan kadar air benih $6 \%$.

\section{Seleksi Bahan Coating Terbaik untuk Benih Cabai}

Rancangan percobaan yang digunakan pada percobaan ini adalah rancangan acak lengkap (RAL) satu faktor yaitu perlakuan pelapisan benih (seed coating). Masing-masing perlakuan dibuat dalam empat ulangan. Setiap unit percobaan terdiri atas 100 butir benih. Perlakuan seed coating yang digunakan sebagai berikut:

1. Kontrol 
2. Arabic gum $20 \%$

3. Arabic gum $50 \%$

4. Na alginat $2.5 \%$

5. Na alginat $5 \%$

6. Xantan gum $2.5 \%$

7. Xantan gum $5 \%$

8. $\mathrm{Na}$ alginat $2.5 \%+$ xantan gum $2.5 \%$

9. Na alginat $5 \%+$ xantan gum $2.5 \%$

10. Na alginat $2.5 \%+x$ antan gum $5 \%$

11. Na alginat $5 \%+$ xantan gum $5 \%$

\section{Pelapisan Benih}

Proses pelapisan benih dilakukan secara manual. Konsentrasi arabic gum 20\% dibuat dengan cara $20 \mathrm{~g}$ arabic gum dilarutkan dalam $100 \mathrm{~mL}$ akuades. Perlakuan coating lainnya dibuat sesuai dengan masing-masing konsentrasi. Benih sebanyak $\pm 7 \mathrm{~g}$ dimasukkan setelah diperoleh larutan yang homogen. Benih diaduk di dalam larutan selama 20 menit sampai merata, kemudian disaring menggunakan saringan berukuran 18 mesh untuk menghilangkan larutan yang tersisa. Benih dikering-anginkan dalam laminar air flow cabinet selama 24 jam, kemudian diukur kadar air benih. Benih yang telah kering diuji viabilitas (daya berkecambah, potensi tumbuh maksimum) dan vigor (indeks vigor, kecepatan tumbuh, keserempakan tumbuh) dengan metode uji di atas kertas menggunakan boks plastik berukuran $14 \mathrm{~cm}$ x 9 $\mathrm{cm} \times 5 \mathrm{~cm}$ pada setiap unit percobaan. Setiap unit percobaan terdiri dari dua boks plastik yang ditanam 50 butir benih dan diletakkan dalam ruangan bersuhu $25-27{ }^{\circ} \mathrm{C}$.

\section{Efektivitas Seed Coating dan Biopriming Benih dengan Rizobakteri dalam Mempertahankan Viabilitas Benih dan Rizobakteri selama Penyimpanan}

Rancangan percobaan yang digunakan adalah petak tersarang (nested design) dua faktor dengan periode simpan $(0,4,8,12,16$, 20, dan 24 minggu) sebagai faktor utama dan perlakuan benih (seed coating dan biopriming) sebagai faktor tersarang. Perlakuan benih pada percobaan ini adalah sebagai berikut:

1. Kontrol

2. Seed coating isolat $\mathrm{E} 1+\mathrm{F} 2 \mathrm{~B} 1$

3. Seed coating isolat ST116B

4. Seed coating isolat CM8

5. Biopriming isolat $\mathrm{E} 1+\mathrm{F} 2 \mathrm{~B} 1$ (24 jam)

6. Biopriming isolat ST116B (24 jam)

7. Biopriming isolat CM8 (24 jam)
8. Biopriming isolat $\mathrm{E} 1+\mathrm{F} 2 \mathrm{~B} 1$ (48 jam)

9. Biopriming isolat ST116B (48 jam)

10. Biopriming isolat CM8 (48 jam)

11. Priming metalaksil 800 ppm (24 jam)

Setiap akhir periode simpan dilakukan pengamatan terhadap viabilitas (daya berkecambah, potensi tumbuh maksimum) dan vigor benih (indeks vigor, kecepatan tumbuh). Jumlah benih yang digunakan dalam pengujian pada setiap unit percorbaan sebanyak 100 butir dengan empat ulangan. Pengamatan meliputi kadar air, populasi rizobakteri di dalam jaringan benih menggunakan dua ulangan.

\section{Perbanyakan Isolat Rizobakteri}

Perbanyakan isolat rizobakteri dilakukan dengan menggunakan media potato dextrose agar (PDA) secara aseptik dalam laminar air flow cabinet, kemudian diinkubasi pada suhu $27-30{ }^{0} \mathrm{C}$ selama 48 jam untuk mendapatkan koloni tunggal. Koloni tunggal kemudian digoreskan pada cawan petri steril yang berisi media PDA dan diinkubasi selama 48 jam pada suhu $27-30{ }^{\circ} \mathrm{C}$. Rizobakteri yang telah diperbanyak pada media PDA digunakan untuk membuat suspensi rizobakteri. Pembuatan suspensi rizobakteri dengan cara rizobakteri yang tumbuh pada media PDA diambil menggunakan jarum ose, kemudian dicampur dengan potato dextrose broth (PDB). Suspensi bakteri digoyang dengan menggunakan rotary shaker selama 48 jam, kemudian kerapatannya menggunakan total plate count (TPC). Kerapatan rizobakteri berdasarkan metode TPC sebagai berikut E1 $=1.4 \times 10^{7} \mathrm{cfu} \mathrm{mL}^{-1}$,

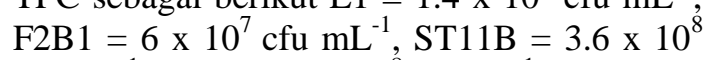
cfu mL ${ }^{-1}, \mathrm{CM} 8=1.6 \times 10^{8} \mathrm{cfu} \mathrm{mL}^{-1}$.

\section{Perlakuan benih}

Benih sebelum diberi perlakuan terlebih dahulu didisinfeksi dengan merendam benih dalam alkohol 70\% selama 3 menit, kemudian dicuci dengan akuades sebanyak tiga kali dan dikering-anginkan dalam laminar air flow cabinet selama 60 menit. Perlakuan coating benih menggunakan formula coating terbaik dari percobaan 1. Pelarut yang digunakan untuk proses coating pada percobaan ini adalah suspensi isolat rizobakteri.

Prosedur coating sama seperti pada percobaan 1. Biopriming dilakukan dengan cara merendam benih dalam $150 \mathrm{~mL}$ suspensi 
rizobakteri selama 24 atau 48 jam pada suhu $26{ }^{0} \mathrm{C}$ (Ibrahim et al., 2014; Rosadiah et al., 2015). Perlakuan priming metalaksil (Saramil, $35 \%$ metalaxyl) dilakukan dengan cara melarutkan $0.12 \mathrm{~g}$ fungisida metalaksil pada $150 \mathrm{~mL}$ akuades, kemudian benih dimasukkan dan direndam selama 24 jam.

Benih yang telah diberi perlakuan kemudian dikering-anginkan dalam laminar air flow cabinet. Perlakuan benih dengan seed coating, biopriming selama 24 jam, fungisida metalaksil, dan kontrol dikeringkan selama 24 jam, sedangkan perlakuan benih dengan biopriming selama 48 jam dikeringkan selama 48 jam sehingga mencapai kadar air $8-10 \%$. Benih cabai yang telah dikering-anginkan kemudian dikemas di dalam plastik polipropilen $0.8 \mathrm{~mm}$ dan disimpan pada suhu $27-30{ }^{\circ} \mathrm{C}$ di dalam boks agar terhindar dari hama tikus.

Data hasil percobaan 1 dan 2 dianalisis dengan menggunakan uji F. Hasil yang menunjukkan berpengaruh nyata dilanjutkan dengan uji lanjut Duncan Multiple Range Test (DMRT) pada taraf 5\%.

\section{HASIL DAN PEMBAHASAN}

\section{Seleksi Bahan Coating Terbaik}

Benih yang telah dilapisi bahan coating mengalami peningkatan bobot benih yang awalnya $\pm 7 \mathrm{~g}$ meningkat menjadi 8-11 $\mathrm{g}$ (Tabel 1). Peningkatan bobot benih terjadi dikarenakan adanya formula coating yang menempel pada permukaan benih cabai. Bahan yang memiliki tekstur yang lebih kental akan menempel pada permukaan benih lebih banyak. Pelapisan benih dengan arabic gum $50 \%$ memiliki peningkatan bobot yang paling besar $4.6 \mathrm{~g}$ yaitu dari $7.0 \mathrm{~g}$ menjadi $11.6 \mathrm{~g}$. Hal ini dikarenakan perlakuan arabic gum memiliki konsentrasi yang paling besar (50\%) diantara sembilan perlakuan lainnya. Selain itu, peningkatan kadar air juga dapat menyebabkan peningkatan bobot benih setelah dilapisi. Kadar air yang masih tinggi disebabkan oleh proses pengeringan yang tidak sempurna dan kekentalan bahan lapisan. Bahan coating yang kental membutuhkan waktu yang lama dalam proses pengeringan sehingga pengeringan 24 jam di dalam laminar air flow tidak cukup sampai menurunkan kadar air benih yang aman.

Perlakuan coating yang tidak berbeda nyata dengan kontrol menunjukkan bahwa bahan coating yang digunakan pada benih cabai tidak mempengaruhi viabilitas dan vigor benih cabai atau tidak bersifat racun terhadap benih (Tabel 2). Perlakuan arabic gum 20\%, natrium alginat $2.5 \%$, natrium alginat $5 \%$ tidak berbeda nyata dengan kontrol pada IV (indeks vigor), $\quad \mathrm{K}_{\mathrm{CT}} \quad$ (kecepatan tumbuh), $\mathrm{K}_{\mathrm{ST}}$ (keserempakan tumbuh), DB (daya berkecambah) dan PTM (potensi tumbuh maksimum). Hal ini menunjukkan bahan coating arabic gum 20\%, natrium alginat $2.5 \%$, dan natrium alginat $5 \%$ tidak bersifat racun dan dapat mempertahankan viabilitas dan vigor benih serta dapat menjadi bahan formula coating terbaik untuk benih cabai.

Tabel 1. Bobot benih (g) dan kadar air (\%) setelah dilakukan pelapisan benih

\begin{tabular}{lcccc}
\hline \multicolumn{1}{c}{ Formula Coating } & $\begin{array}{c}\text { Bobot Sebelum } \\
\text { Dilapisi } \\
(\mathrm{g})\end{array}$ & $\begin{array}{c}\text { Bobot Setelah } \\
\text { Dilapisi } \\
(\mathrm{g})\end{array}$ & $\begin{array}{c}\text { Peningkatan } \\
\text { Bobot } \\
(\mathrm{g})\end{array}$ & $\begin{array}{c}\text { KA } \\
(\%)\end{array}$ \\
\hline Arabic gum 20\% & 7.0 & 10.2 & 3.1 & 20.7 \\
Arabic gum 50\% & 7.0 & 11.6 & 4.6 & 14.0 \\
Na alginat 2.5\% & 7.0 & 7.9 & 0.9 & 13.8 \\
Na alginat 5\% & 7.0 & 8.9 & 1.9 & 24.8 \\
Xantan gum 2.5\% & 7.0 & 7.8 & 0.7 & 12.4 \\
Xantan gum 5\% & 7.0 & 9.1 & 2.1 & 22.9 \\
Na alginat 2.5\% + xantan gum 2.5\% & 7.0 & 8.9 & 1.9 & 20.4 \\
Na alginat 5\% + xantan gum 2.5\% & 7.0 & 8.9 & 1.9 & 15.8 \\
Na alginat 2.5\% + xantan gum 5\% & 7.0 & 9.5 & 2.5 & 21.1 \\
Na alginat 5\% + xantan gum 5\% & 7.0 & 9.6 & 2.6 & 19.1 \\
\hline Keterangan KA
\end{tabular}


Tabel 2. Pengaruh pelapisan benih cabai terhadap viabilitas dan vigor benih

\begin{tabular}{lccccc}
\hline \multirow{2}{*}{ Formula Coating } & $\begin{array}{c}\mathrm{IV} \\
\%\end{array}$ & $\begin{array}{c}\mathrm{K}_{\mathrm{CT}} \\
\% / \mathrm{etmal}\end{array}$ & $\begin{array}{c}\mathrm{K}_{\mathrm{ST}} \\
\%\end{array}$ & $\begin{array}{c}\mathrm{DB} \\
\%\end{array}$ & $\begin{array}{c}\text { PTM } \\
\%\end{array}$ \\
\hline Kontrol & $12.0 \mathrm{a}$ & $9.9 \mathrm{a}$ & $59.0 \mathrm{a}$ & $90.8 \mathrm{a}$ & $98.5 \mathrm{a}$ \\
AG 20\% & $7.3 \mathrm{abc}$ & $9.6 \mathrm{ab}$ & $60.0 \mathrm{a}$ & $88.8 \mathrm{ab}$ & $97.3 \mathrm{a}$ \\
AG 50\% & $5.8 \mathrm{bcd}$ & $9.3 \mathrm{~b}$ & $62.3 \mathrm{a}$ & $87.5 \mathrm{ab}$ & $98.0 \mathrm{a}$ \\
NA 2.5\% & $10.5 \mathrm{a}$ & $9.9 \mathrm{a}$ & $66.3 \mathrm{a}$ & $88.3 \mathrm{ab}$ & $98.3 \mathrm{a}$ \\
NA 5\% & $10.0 \mathrm{ab}$ & $10.2 \mathrm{a}$ & $67.3 \mathrm{a}$ & $91.3 \mathrm{a}$ & $97.8 \mathrm{a}$ \\
XG 2.5\% & $7.0 \mathrm{abc}$ & $9.3 \mathrm{~b}$ & $59.0 \mathrm{a}$ & $87.3 \mathrm{ab}$ & $98.3 \mathrm{a}$ \\
XG 5\% & $3.0 \mathrm{~cd}$ & $7.5 \mathrm{de}$ & $37.8 \mathrm{bc}$ & $77.0 \mathrm{c}$ & $96.5 \mathrm{ab}$ \\
NA 2.5\% + XG 2.5\% & $5.3 \mathrm{~cd}$ & $8.4 \mathrm{c}$ & $45.5 \mathrm{~b}$ & $83.0 \mathrm{bc}$ & $95.8 \mathrm{abc}$ \\
NA 5\% + XG 2.5\% & $4.8 \mathrm{~cd}$ & $7.8 \mathrm{~cd}$ & $44.8 \mathrm{~b}$ & $76.5 \mathrm{c}$ & $93.0 \mathrm{~cd}$ \\
NA 2.5\% XG 5\% & $4.8 \mathrm{~cd}$ & $7.8 \mathrm{~cd}$ & $38.3 \mathrm{bc}$ & $78.3 \mathrm{c}$ & $94.0 \mathrm{bcd}$ \\
NA 5\%+XG 5\% & $1.3 \mathrm{~d}$ & $6.9 \mathrm{e}$ & $34.8 \mathrm{c}$ & $76.5 \mathrm{c}$ & $92.0 \mathrm{~d}$ \\
\hline KK $(\%)$ & 10.4 & 6.7 & 10.6 & 5.5 & 1.9 \\
\hline Ke
\end{tabular}

Keterangan: $\mathrm{AG}=$ arabic gum, $\mathrm{NA}=$ natrium alginat, $\mathrm{XG}=$ xantan gum, $\mathrm{IV}=$ indeks vigor, $\mathrm{K}_{\mathrm{CT}}=$ kecepatan tumbuh, $\mathrm{K}_{\mathrm{ST}}=$ keserempakan tumbuh, $\mathrm{DB}=$ daya berkecambah, $\mathrm{PTM}=$ potensi tumbuh maksimum. Data indeks vigor adalah data hasil transformasi $\ln (x+5)$. Data yang ditampilkan merupakan data sebenarnya. Angka yang diikuti huruf yang sama pada setiap kolom tidak berbeda nyata pada taraf $5 \%$ berdasarkan uji DMRT.

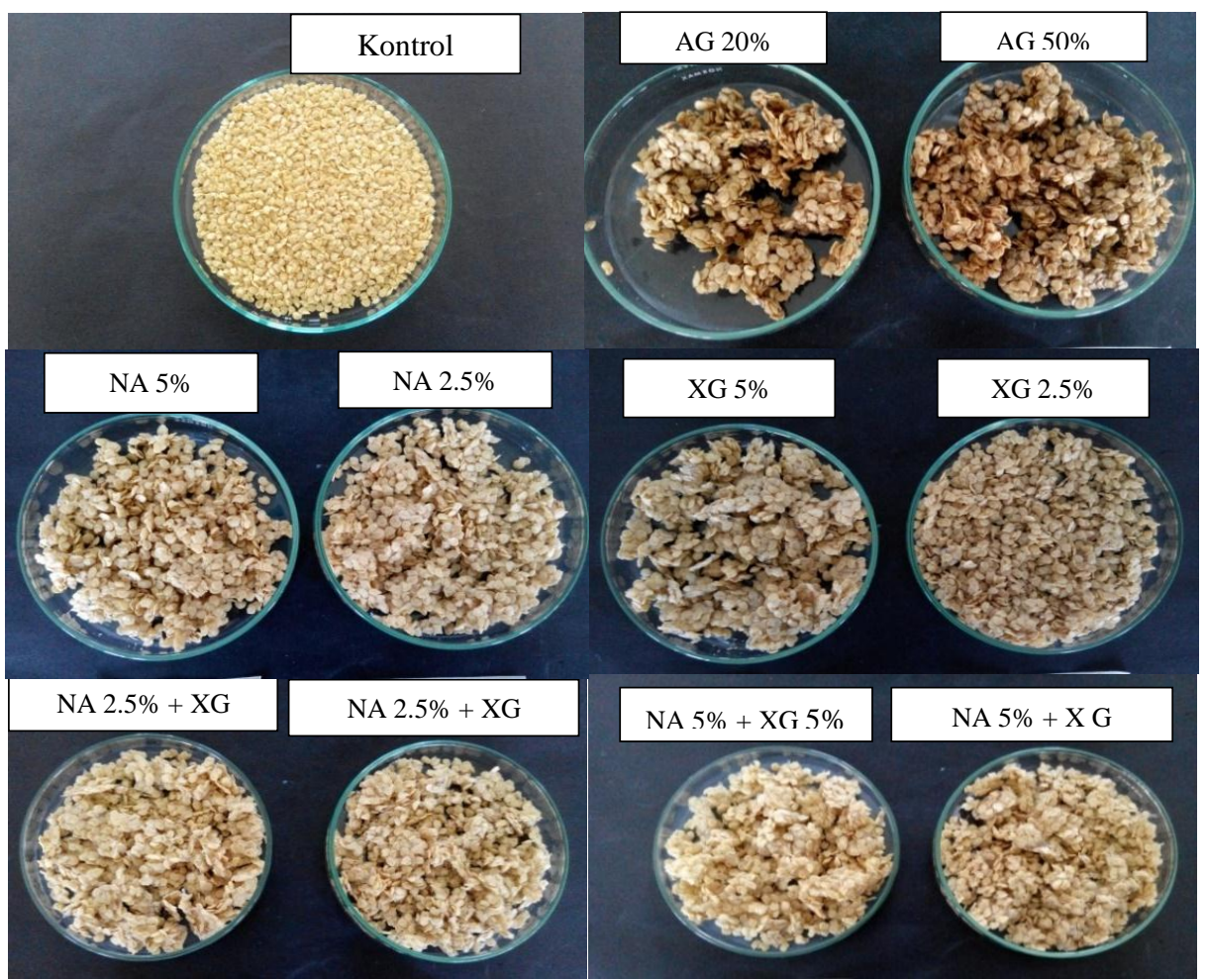

Gambar 1. Hasil perlakuan coating pada benih cabai. $\mathrm{AG}=$ arabic gum, $\mathrm{NA}=$ natrium alginat, $\mathrm{XG}=$ xantan gum.

Hasil penelitian Malabadi dan Staden (2005), apeks vegetatif embrio somatik pinus yang dienkapsulasi menggunakan natrium alginat 2.5\% memberikan perkecambahan paling tinggi sebesar 89\%. Anis et al. (2012) menunjukkan benih sun flower yang dilapisi natrium alginat $1 \%$ dan $2 \%$ secara signifikan meningkatkan daya berkecambah $100 \%$ dibandingkan dengan kontrol. Menurut Palupi et al. (2013), campuran formula alginat 3\% plus gambut $1 \%$ dapat mempertahankan vigor 
benih padi sebesar $12 \%$ setelah disimpan selama 2 bulan.

Benih cabai yang dilapisi dengan arabic gum mengalami perubahan warna dari warna asli menjadi warna coklat mengkilap (Gambar 1). Formula coating terbaik untuk benih cabai berdasarkan pengujian viabilitas dan vigor benih, penampilan benih cabai setelah dilapisi bahan coating, efisiensi penggunaan bahan coating adalah $\mathrm{Na}$ alginat $2.5 \%$. Bahan coating $\mathrm{Na}$ alginat $2.5 \%$ selanjutnya digunakan pada percobaan kedua.

\section{Efektivitas Seed Coating dan Biopriming Benih dengan Rizobakteri dalam Mempertahankan Viabilitas Benih dan Rizobakteri selama Penyimpanan}

Kadar air benih selama proses penyimpanan mengalami fluktuasi (Tabel 3). Menurut Justice dan Bass (2002), adanya fluktuasi kadar air disebabkan oleh sifat benih yang higroskopis sehingga benih akan selalu menyesuaikan dengan keseimbangan udara di sekitarnya. Kemasan plastik yang kurang mampu melindungi benih dari oksigen, air dan karbondioksida sehingga udara yang masuk ke dalam kemasan dapat menyebabkan peningkatan kadar air. Kadar air sampai periode simpan 24 minggu masih 9.2 - 10.3\% (Tabel 3). Kadar air tersebut masih aman untuk disimpan.
Menurut Copeland dan McDonald (2001), kadar air benih tidak boleh melebihi $14 \%$ maupun di bawah 5\%. Penyimpanan benih berkadar air di atas $14 \%$ dapat meningkatkan respirasi dan panas serta serangan cendawan yang dapat menurunkan viabilitas benih secara cepat. Perlakuan benih dengan seed coating mengalami peningkatan kadar air lebih tinggi sampai akhir periode simpan dibandingkan perlakuan lainnya. Menurut Sari (2009) alginat memiliki sifat yang mudah menyerap air ketika dilarutkan, sehingga pengeringan yang tidak sempurna pada proses coating dapat menyebabkan peningkatan kadar air. Mushollaeni dan Rusdiana (2011) melaporkan semakin besar luas permukaan alginat, semakin mudah tepung alginat menyerap air.

Kecepatan tumbuh menunjukkan penurunan mulai periode simpan 16 hingga 24 minggu (Tabel 4). Perlakuan priming fungisida metalaksil paling signifikan mengalami penurunan kecepatan tumbuh dari $11.7 \%$ / etmal (0 minggu simpan) menjadi 5.9\%/etmal (24 minggu simpan). Hal ini sejalan dengan penelitian Setiyowati et al. (2007) yang melaporkan penggunaan seed coating dengan fungisida benomil dapat menurunkan kecepatan tumbuh pada benih cabai besar (Capsicum annuum L.).

Tabel 3. Pengaruh periode simpan dan perlakuan benih terhadap kadar air (\%)

\begin{tabular}{|c|c|c|c|c|c|c|c|c|c|}
\hline \multirow{2}{*}{$\begin{array}{l}\text { Perlakuan } \\
\text { Benih }\end{array}$} & \multicolumn{9}{|c|}{ Periode Simpan (minggu) } \\
\hline & 0 & & 4 & & 8 & 12 & 16 & 20 & 24 \\
\hline P0 & $8.5 \mathrm{Bd}$ & 9.2 & $\mathrm{ABc}$ & 9.0 & $\mathrm{ABc}$ & $9.1 \mathrm{Bc}$ & $10.8 \mathrm{BCa}$ & $10.4 \mathrm{Aab}$ & $9.4 \mathrm{Abc}$ \\
\hline $\mathrm{P} 1$ & $8.8 \mathrm{Bc}$ & 9.6 & $\mathrm{ABbc}$ & 9.6 & $\mathrm{ABbc}$ & $9.8 \mathrm{Bbc}$ & 10.1 Cab & $11.2 \mathrm{Aa}$ & $10.3 \mathrm{Aab}$ \\
\hline $\mathrm{P} 2$ & 9.5 Abbc & 9.6 & $\mathrm{ABbc}$ & 9.0 & $\mathrm{ABc}$ & $11.8 \mathrm{Aa}$ & $11.8 \mathrm{ABa}$ & $11.2 \mathrm{Aa}$ & $10.3 \mathrm{Ab}$ \\
\hline P3 & $9.5 \mathrm{Abc}$ & 9.6 & $\mathrm{ABc}$ & 10.1 & Abc & $10.0 \mathrm{Bbc}$ & $11.3 \mathrm{ABa}$ & 11.1 Aab & 10.1 Abc \\
\hline $\mathrm{P} 4$ & $8.9 \mathrm{Bb}$ & 9.0 & $\mathrm{ABb}$ & 8.3 & $\mathrm{Bb}$ & $9.4 \mathrm{Bb}$ & $10.7 \mathrm{ABa}$ & 10.9 Аa & $9.4 \mathrm{Ab}$ \\
\hline P5 & 9.1 Abd & 9.4 & $\mathrm{ABb}$ & 8.5 & $\mathrm{Bb}$ & $9.3 \mathrm{Bb}$ & $10.5 \mathrm{Ca}$ & $10.5 \mathrm{Aa}$ & $9.3 \mathrm{Ab}$ \\
\hline P6 & 10.2 Aab & 10.3 & Aab & 10.2 & $\mathrm{Aab}$ & $9.7 \mathrm{Bb}$ & $10.9 \mathrm{BCa}$ & 10.5 Aab & $9.8 \mathrm{Aab}$ \\
\hline P7 & $9.0 \mathrm{Bc}$ & 9.0 & $\mathrm{Bc}$ & 9.0 & $\mathrm{ABc}$ & $9.2 \mathrm{Bc}$ & $12.0 \mathrm{Aa}$ & $10.4 \mathrm{Ab}$ & $9.2 \mathrm{Ac}$ \\
\hline P8 & $8.8 \mathrm{Bb}$ & 9.3 & $\mathrm{ABab}$ & 9.1 & $\mathrm{ABb}$ & $9.2 \mathrm{Bb}$ & 10.1 Cab & $10.5 \mathrm{Aa}$ & $9.4 \mathrm{Aab}$ \\
\hline P9 & $8.9 \mathrm{Bbc}$ & 9.2 & $\mathrm{ABbc}$ & 8.2 & $\mathrm{Bc}$ & $9.2 \mathrm{Bbc}$ & $10.8 \mathrm{BCa}$ & $11.0 \mathrm{Aa}$ & $9.5 \mathrm{Ab}$ \\
\hline P10 & $9.3 \mathrm{Abb}$ & 9.8 & $\mathrm{ABb}$ & 9.0 & $\mathrm{ABb}$ & $9.4 \mathrm{Bb}$ & $10.7 \mathrm{BCa}$ & 10.4 Aab & $9.3 \mathrm{Ab}$ \\
\hline
\end{tabular}

Keterangan: $\mathrm{P} 0=$ kontrol tanpa diberi perlakuan rizobakteri, $\mathrm{P} 1=$ seed coating $\mathrm{E} 1+\mathrm{F} 2 \mathrm{~B} 1, \mathrm{P} 2=$ seed coating ST116B, P3 = seed coating CM8, P4 = biopriming E1 + F2B1 24 jam, P5 = biopriming ST116B 24 jam, P6 = biopriming CM8 24 jam, P7 = biopriming E1 + F2B1 48 jam, P8 = biopriming ST116B 48 jam, P9 = biopriming CM8 48 jam, P10 = priming dengan fungisida metalaksil. P0, P1, P2, P3, P4, P5, P6, P10 dikeringkan dalam laminar air flow cabinet selama 24 jam, sedangkan P7, P8, P9 dikeringkan selama 48 jam. Angka yang diikuti huruf yang sama pada kolom atau baris yang sama menunjukkan tidak berbeda nyata pada berdasaran DMRT taraf 5\%. Huruf kecil ke samping (dalam satu baris) menunjukkan pengaruh periode simpan sedangkan huruf kapital ke bawah (dalam satu kolom) menunjukkan pengaruh perlakuan benih. 
Perlakuan seed coating menghasilkan nilai indeks vigor yang lebih kecil dibanding perlakuan lainnya dan kontrol (Tabel 5). Hal ini kemungkinan disebabkan oleh dua hal yaitu 1) lapisan coating yang kering dan keras pada benih mengakibatkan waktu imbibisi benih menjadi lebih lama karena menunggu lapisan tersebut larut dengan air terlebih dahulu, 2) lapisan coating menghambat radikula untuk keluar. Indeks vigor pada semua perlakuan mengalami peningkatan pada periode simpan 4 dan 8 minggu, kemudian menurun sampai akhir periode simpan. Penurunan indeks vigor dipengaruhi oleh peningkatan kadar air (Tabel 3). Perlakuan benih yang mampu mempertahankan indeks vigor paling tinggi setelah disimpan selama 24 minggu adalah P9 (biopriming dengan isolat CM8 selama 48 jam) dan P4 (biopriming dengan isolat E1 + F2B1 selama 24 jam).

Perlakuan benih dengan rizobakteri tidak berbeda nyata dengan kontrol pada variabel daya berkecambah dan potensi tumbuh maksimum (Tabel 6). Menurut Diniz et al. (2009), benih yang dilapisi dengan Trichoderma viride, T. polysporhum, $T$. stromaticum, Beauveria bassiana, Metarhizium anisopliae tidak menunjukkan peningkatan signifikan pada variabel daya berkecambah karena benih masih memiliki vigor yang tinggi. Pada periode simpan 20 minggu daya berkecambah juga mengalami penurunan tetapi tidak signifikan. Penyebabnya adalah serangan cendawan penyimpanan (storage fungi) yaitu Aspergillus niger, dan peningkatan kadar air (Tabel 3) sehingga kecambah tumbuh abnormal atau benih menjadi busuk. Hal ini menunjukkan bahwa plastik polipropilen $0.8 \mathrm{~mm}$ kurang mampu melindungi benih dari udara yang masuk ke dalam kemasan sehingga terjadi peningkatan kadar air dan serangan cendawan yang dapat menurunkan mutu benih.

Pada periode simpan 24 minggu, daya berkecambah benih yang diberi perlakuan dengan rizobakteri masih 79.3-88.5\%, sedangkan pada perlakuan metalaksil $54.3 \%$ (Tabel 6). Potensi tumbuh maksimum pada benih yang diberi perlakuan metalaksil juga mengalami penurunan signifikan dari $92.0 \%$ menjadi $61.8 \%$ pada akhir periode simpan. Hal ini kemungkinan disebabkan fungisida metalaksil bersifat fitotoksik dalam jangka waktu yang lama jika diberikan pada benih sehingga berdampak negatif pada viabilitas dan vigor benih. Pada saat dikecambahkan, benih yang diberikan perlakuan fungisida metalaksil banyak yang tidak tumbuh dan tumbuh abnormal.

Tabel 4. Pengaruh periode simpan dan perlakuan benih terhadap kecepatan tumbuh (\%/etmal)

\begin{tabular}{|c|c|c|c|c|c|c|c|c|c|c|c|c|}
\hline \multirow{2}{*}{$\begin{array}{l}\text { Perlakuan } \\
\text { Benih }\end{array}$} & \multicolumn{12}{|c|}{ Periode Simpan (minggu) } \\
\hline & & 0 & & 4 & & 8 & & 12 & & 16 & 20 & 24 \\
\hline $\mathrm{P} 0$ & 10.7 & $\mathrm{ABa}$ & 10.2 & $\mathrm{Aab}$ & 11.5 & $\mathrm{ABa}$ & 10.2 & $\mathrm{ABab}$ & 10.5 & $\mathrm{Aab}$ & 10.1 Aab & $10.1 \mathrm{ABab}$ \\
\hline $\mathrm{P} 1$ & 9.4 & $\mathrm{Bab}$ & 9.8 & $\mathrm{ABab}$ & 10.2 & $\mathrm{Ba}$ & 10.5 & $\mathrm{ABa}$ & 10.3 & $\mathrm{Aa}$ & 9.4 ABab & 9.5 ABab \\
\hline $\mathrm{P} 2$ & 9.8 & $\mathrm{Bbc}$ & 9.3 & $\mathrm{ABbc}$ & 11.7 & $\mathrm{ABa}$ & 11.1 & $\mathrm{Aa}$ & 10.4 & Aab & 9.4 ABbc & $8.7 \mathrm{Bc}$ \\
\hline P3 & 9.8 & $\mathrm{Bab}$ & 9.8 & $\mathrm{ABb}$ & 10.9 & $\mathrm{ABa}$ & 10.3 & $\mathrm{ABa}$ & 9.9 & $\mathrm{ABab}$ & $9.3 \mathrm{ABab}$ & 9.5 ABab \\
\hline P4 & 10.2 & $\mathrm{ABab}$ & 10.8 & Aa & 11.4 & $\mathrm{ABa}$ & 10.1 & $\mathrm{ABab}$ & 10.7 & $\mathrm{Aa}$ & 10.2 Aab & $10.4 \mathrm{Aa}$ \\
\hline P5 & 10.0 & $\mathrm{Bb}$ & 10.3 & $\mathrm{Ab}$ & 12.3 & $\mathrm{Aa}$ & 11.1 & $\mathrm{Aab}$ & 10.4 & $\mathrm{Ab}$ & $9.4 \mathrm{ABbc}$ & $9.8 \mathrm{ABbc}$ \\
\hline P6 & 10.3 & $\mathrm{ABab}$ & 10.6 & $\mathrm{Aa}$ & 11.5 & $\mathrm{ABa}$ & 11.4 & $\mathrm{Aa}$ & 10.9 & $\mathrm{Aa}$ & $10.7 \mathrm{Aa}$ & $10.0 \mathrm{ABab}$ \\
\hline P7 & 10.8 & $\mathrm{ABa}$ & 10.3 & $\mathrm{Aab}$ & 11.1 & $\mathrm{ABa}$ & 10.2 & $\mathrm{ABab}$ & 10.0 & $\mathrm{ABab}$ & $9.8 \mathrm{ABab}$ & $9.0 \mathrm{Bb}$ \\
\hline P8 & 10.6 & Ababc & 10.1 & $\mathrm{Abc}$ & 11.8 & $\mathrm{ABa}$ & 11.4 & $\mathrm{Aab}$ & 10.3 & Aabc & $9.7 \mathrm{ABc}$ & $8.8 \mathrm{Bc}$ \\
\hline P9 & 10.3 & $\mathrm{ABab}$ & 10.1 & $\mathrm{Aab}$ & 11.2 & $\mathrm{ABa}$ & 11.7 & $\mathrm{Aa}$ & 9.9 & $\mathrm{ABab}$ & $11.0 \mathrm{Aa}$ & $10.6 \mathrm{Aab}$ \\
\hline $\mathrm{P} 10$ & 11.7 & $\mathrm{Aa}$ & 10.8 & $\mathrm{Aab}$ & 11.9 & $\mathrm{Aa}$ & 11.3 & Aab & 10.0 & $\mathrm{ABb}$ & $8.4 \mathrm{Bc}$ & $5.9 \mathrm{Cd}$ \\
\hline
\end{tabular}

Keterangan: $\mathrm{P} 0=$ kontrol tanpa diberi perlakuan rizobakteri, $\mathrm{P} 1=$ seed coating $\mathrm{E} 1+\mathrm{F} 2 \mathrm{~B} 1, \mathrm{P} 2$ = seed coating ST116B, P3 = seed coating CM8, P4 = biopriming E1 + F2B1 24 jam, P5 = biopriming ST116B 24 jam, P6 = biopriming CM8 24 jam, P7 = biopriming E1 + F2B1 48 jam, P8 = biopriming ST116B 48 jam, $\mathrm{P} 9$ = biopriming CM8 48 jam, $\mathrm{P} 10$ = priming dengan fungisida metalaksil. $\mathrm{P} 0, \mathrm{P} 1, \mathrm{P} 2, \mathrm{P} 3, \mathrm{P} 4, \mathrm{P} 5$, P6, P10 dikeringkan dalam laminar air flow cabinet selama 24 jam, sedangkan P7, P8, P9 dikeringkan selama 48 jam. Angka yang diikuti huruf yang sama pada kolom atau baris yang sama menunjukkan tidak berbeda nyata pada berdasaran DMRT taraf 5\%. Huruf kecil ke samping (dalam satu baris) menunjukkan pengaruh periode simpan sedangkan huruf kapital ke bawah (dalam satu kolom) menunjukkan pengaruh perlakuan benih. 
Tabel 5. Pengaruh periode simpan dan perlakuan benih terhadap indeks vigor (\%)

\begin{tabular}{|c|c|c|c|c|c|c|c|c|c|c|c|c|}
\hline \multirow{2}{*}{$\begin{array}{l}\text { Perlakuan } \\
\text { Benih } \\
\mathrm{P} 0\end{array}$} & \multicolumn{12}{|c|}{ Periode Simpan (minggu) } \\
\hline & \multicolumn{2}{|c|}{0} & \multicolumn{2}{|c|}{4} & \multicolumn{2}{|c|}{8} & \multicolumn{2}{|c|}{12} & \multicolumn{2}{|c|}{20} & \multicolumn{2}{|c|}{24} \\
\hline $\mathrm{P} 0$ & 12.5 & $\mathrm{BCDc}$ & 27.8 & $\mathrm{Cb}$ & 51.0 & $\mathrm{CDa}$ & 27.3 & $\mathrm{DEb}$ & 21.5 & $\mathrm{BCbc}$ & 12.5 & $\mathrm{BCc}$ \\
\hline P1 & 3.3 & Dc & 11.0 & Dbc & 19.0 & Eab & 20.8 & $\mathrm{EFa}$ & 11.5 & CDbc & 4.0 & $\mathrm{CDc}$ \\
\hline $\mathrm{P} 2$ & 8.3 & CDcd & 11.0 & Ded & 42.8 & $\mathrm{Da}$ & 26.5 & $\mathrm{DEb}$ & 9.0 & Dcd & 2.3 & Dd \\
\hline P3 & 5.5 & $\mathrm{Dd}$ & 11.8 & Dbcd & 27.5 & $\mathrm{Ea}$ & 15.0 & $\mathrm{Fbc}$ & 8.8 & Dcd & 3.0 & CDd \\
\hline P4 & 15.5 & $\mathrm{BCc}$ & 37.3 & $\mathrm{BCb}$ & 56.8 & $\mathrm{BCa}$ & 34.8 & $\mathrm{BCDb}$ & 31.8 & $\mathrm{Ab}$ & 18.5 & $\mathrm{ABc}$ \\
\hline P5 & 18.5 & $\mathrm{Bc}$ & 38.0 & $\mathrm{Bb}$ & 64.8 & $\mathrm{Aa}$ & 39.5 & $\mathrm{ABb}$ & 15.0 & CDcd & 7.5 & $\mathrm{CDd}$ \\
\hline P6 & 18.3 & $\mathrm{Bd}$ & 41.3 & $\mathrm{Bb}$ & 52.8 & $\mathrm{CDa}$ & 29.5 & CDEc & 28.5 & $\mathrm{ABc}$ & 11.5 & $\mathrm{BCd}$ \\
\hline P7 & 18.5 & $\mathrm{Bc}$ & 35.0 & $\mathrm{BCb}$ & 48.5 & $\mathrm{Da}$ & 30.5 & $\mathrm{CDb}$ & 15.0 & CDcd & 8.8 & $\mathrm{CDd}$ \\
\hline P8 & 18.0 & $\mathrm{Bc}$ & 35.3 & $\mathrm{BCb}$ & 50.5 & $\mathrm{CDa}$ & 38.0 & $\mathrm{BCb}$ & 19.5 & $\mathrm{BCc}$ & 5.0 & CDd \\
\hline P9 & 14.0 & BCDd & 33.0 & $\mathrm{BCb}$ & 47.5 & $\mathrm{Da}$ & 47.0 & $\mathrm{Aa}$ & 27.5 & $\mathrm{ABbc}$ & 21.5 & Acd \\
\hline $\mathrm{P} 10$ & 31.8 & Ac & 55.3 & $\mathrm{Aa}$ & 62.0 & $\mathrm{ABa}$ & 41.3 & $\mathrm{ABb}$ & 11.8 & CDd & 5.8 & $\mathrm{CDd}$ \\
\hline
\end{tabular}

Keterangan: $\mathrm{P} 0=$ kontrol tanpa diberi perlakuan rizobakteri, $\mathrm{P} 1=$ seed coating $\mathrm{E} 1+\mathrm{F} 2 \mathrm{~B} 1, \mathrm{P} 2=$ seed coating $\mathrm{ST} 116 \mathrm{~B}, \mathrm{P} 3=$ seed coating $\mathrm{CM} 8, \mathrm{P} 4=$ biopriming $\mathrm{E} 1+\mathrm{F} 2 \mathrm{~B} 124 \mathrm{jam}, \mathrm{P} 5=$ biopriming $\mathrm{ST} 116 \mathrm{~B} 24$ jam, $\mathrm{P} 6=$ biopriming CM8 24 jam, P7 = biopriming E1 + F2B1 48 jam, P8 = biopriming ST116B 48 jam, P9 = biopriming CM8 48 jam, $\mathrm{P} 10=$ priming dengan fungisida metalaksil. P0, P1, P2, P3, P4, P5, P6, P10 dikeringkan dalam laminar air flow cabinet selama 24 jam, sedangkan P7, P8, P9 dikeringkan selama 48 jam. Angka yang diikuti huruf yang sama pada kolom atau baris yang sama menunjukkan tidak berbeda nyata pada berdasaran DMRT taraf 5\%. Huruf kecil ke samping (dalam satu baris) menunjukkan pengaruh periode simpan sedangkan huruf kapital ke bawah (dalam satu kolom) menunjukkan pengaruh perlakuan benih.

Tabel 6. Pengaruh periode simpan dan perlakuan benih terhadap daya berkecambah dan potensi tumbuh maksimum

\begin{tabular}{|c|c|c|c|c|c|c|c|c|c|c|c|}
\hline \multirow{2}{*}{$\begin{array}{c}\text { Perlakuan } \\
\text { Benih }\end{array}$} & \multicolumn{11}{|c|}{ Periode Simpan (minggu) } \\
\hline & & 0 & & 4 & & 8 & & 2 & 16 & 20 & 24 \\
\hline & \multicolumn{11}{|c|}{ Daya berkecambah $(\%)$} \\
\hline P0 & 90.5 & Aa & 85.0 & Aab & 87.5 & $\mathrm{ABab}$ & 78.8 & $\mathrm{ABb}$ & 86.5 Aab & 82.0 Aab & 87.0 ABab \\
\hline P1 & 89.5 & $\mathrm{Aa}$ & 89.3 & Aa & 88.0 & Aab & 85.0 & Aab & $87.8 \mathrm{Aab}$ & $79.8 \mathrm{ABb}$ & 88.5 Aab \\
\hline $\mathrm{P} 2$ & 89.5 & $\mathrm{Aa}$ & 84.0 & Aab & 90.8 & $\mathrm{Aa}$ & 87.0 & $\mathrm{Aa}$ & 89.8 Аа & 82.0 Aab & 84.3 ABab \\
\hline P3 & 90.8 & $\mathrm{Aa}$ & 87.0 & Aab & 89.8 & Aa & 85.8 & Aab & $87.5 \mathrm{Aab}$ & $80.0 \mathrm{ABb}$ & $88.3 \mathrm{Aab}$ \\
\hline P4 & 87.5 & $\mathrm{ABa}$ & 87.0 & $\mathrm{Aa}$ & 85.5 & $\mathrm{ABa}$ & 75.5 & $\mathrm{Bb}$ & 87.0 Aa & 80.3 ABab & $85.0 \mathrm{ABa}$ \\
\hline P5 & 84.3 & $\mathrm{ABab}$ & 82.0 & $\mathrm{ABab}$ & 90.3 & Aa & 83.3 & $\mathrm{ABab}$ & $87.8 \mathrm{Aab}$ & $79.5 \mathrm{ABb}$ & $86.3 \mathrm{ABab}$ \\
\hline P6 & 86.5 & $\mathrm{ABa}$ & 84.5 & $\mathrm{Aa}$ & & $\mathrm{Aa}$ & 84.5 & $\mathrm{Aa}$ & $89.0 \mathrm{Aa}$ & $84.8 \mathrm{Aa}$ & $5.5 \mathrm{ABa}$ \\
\hline P7 & 89.8 & $\mathrm{Aa}$ & 84 & Aab & & $\mathrm{ABab}$ & 79.0 & $\mathrm{ABb}$ & 83.3 ABab & $81.5 \mathrm{Aab}$ & $79.3 \mathrm{Bb}$ \\
\hline P8 & 88. & $\mathrm{Aab}$ & & $\mathrm{ABabc}$ & & $\mathrm{Aa}$ & 86.8 & Aabc & 86.0 Aabc & $79.8 \mathrm{ABc}$ & $80.0 \mathrm{ABbc}$ \\
\hline P9 & 90.3 & $\mathrm{Aa}$ & 82.5 & $\mathrm{ABa}$ & 85.3 & $\mathrm{ABa}$ & 84.0 & $\mathrm{ABa}$ & $82.0 \mathrm{AF}$ & $88.3 \mathrm{Aa}$ & $86.3 \mathrm{ABa}$ \\
\hline \multirow[t]{2}{*}{ P10 } & 92.0 & $\mathrm{Aa}$ & & $\mathrm{ABab}$ & & $\mathrm{ABab}$ & 82.5 & $\mathrm{ABab}$ & $81.3 \mathrm{ABb}$ & $71.3 \mathrm{Cc}$ & $54.3 \mathrm{Cd}$ \\
\hline & \multicolumn{11}{|c|}{ Potensi Tumbuh Maksimum (\%) } \\
\hline P0 & 96.8 & Aa & 97.0 & $\mathrm{Aa}$ & 92.5 & $\mathrm{ABab}$ & 93.5 & $\mathrm{Aab}$ & $95.3 \mathrm{Aab}$ & $93.3 \mathrm{Aab}$ & $89.8 \mathrm{ABCb}$ \\
\hline P1 & 94.5 & $\mathrm{Aa}$ & 96.8 & A a & 92.5 & $\mathrm{ABa}$ & 95.0 & $\mathrm{Aa}$ & $93.8 \mathrm{Aa}$ & $92.8 \mathrm{ABa}$ & $91.8 \mathrm{ABa}$ \\
\hline $\mathrm{P} 2$ & 95.3 & $\mathrm{Aa}$ & 94.3 & $\mathrm{Aa}$ & 93.3 & $\mathrm{Aa}$ & 94.3 & Aa & $93.8 \mathrm{Aa}$ & $91.3 \mathrm{ABa}$ & 90.0 ABCab \\
\hline P3 & 96.0 & $\mathrm{Aa}$ & 94.8 & $\mathrm{Aa}$ & 94.8 & $\mathrm{Aa}$ & 92.8 & $\mathrm{Aa}$ & $93.3 \mathrm{Aa}$ & $91.5 \mathrm{ABa}$ & $93.3 \mathrm{Aa}$ \\
\hline P4 & 94.5 & $\mathrm{Aa}$ & 95.5 & $\mathrm{Aa}$ & 92.0 & $\mathrm{ABa}$ & 91.8 & $\mathrm{ABa}$ & $93.0 \mathrm{Aa}$ & $93.3 \mathrm{Aa}$ & $91.3 \mathrm{ABa}$ \\
\hline P5 & 91.3 & $\mathrm{ABab}$ & 96.3 & $\mathrm{Aa}$ & 93.5 & $A a b$ & 90.0 & $\mathrm{ABb}$ & $93.3 \mathrm{Aab}$ & $93.8 \mathrm{Aab}$ & $90.5 \mathrm{ABab}$ \\
\hline P6 & 94.8 & Aab & 95.5 & $\mathrm{Aa}$ & 92.5 & $\mathrm{ABab}$ & 88.0 & $\mathrm{ABb}$ & $93.0 \mathrm{Aab}$ & $94.5 \mathrm{Aab}$ & 89.5 ABCb \\
\hline P7 & 95.3 & $\mathrm{Aa}$ & 94.5 & $\mathrm{Aa}$ & 91.8 & $\mathrm{ABab}$ & 89.5 & $\mathrm{ABab}$ & $91.8 \mathrm{ABab}$ & $93.0 \mathrm{Aa}$ & $86.8 \mathrm{BCb}$ \\
\hline P8 & 94.0 & $\mathrm{Aa}$ & 93.5 & $\mathrm{Aa}$ & 96.0 & $\mathrm{Aa}$ & 93.3 & & $93.3 \mathrm{Aa}$ & 90.5 ABab & $85.5 \mathrm{Cb}$ \\
\hline P9 & 95.5 & $\mathrm{Aa}$ & 94.5 & $\mathrm{Aa}$ & 92.3 & $\mathrm{ABa}$ & 95.3 & $\mathrm{Aa}$ & $91.3 \mathrm{ABa}$ & $95.0 \mathrm{Aa}$ & $92.0 \mathrm{ABa}$ \\
\hline P10 & 95.5 & $\mathrm{Aa}$ & 92.5 & $\mathrm{ABab}$ & 91.8 & $\mathrm{ABab}$ & 93.0 & $\mathrm{Aa}$ & $90.5 \mathrm{ABab}$ & $87.0 \mathrm{Bb}$ & $61.8 \mathrm{Dc}$ \\
\hline \multicolumn{12}{|c|}{$\begin{array}{l}\text { Keterangan: } \mathrm{P} 0=\text { kontrol tanpa diberi perlakuan rizobakteri, } \mathrm{P} 1=\text { seed coating } \mathrm{E} 1+\mathrm{F} 2 \mathrm{~B} 1, \mathrm{P} 2=\text { seed coating } \mathrm{ST} 116 \mathrm{~B}, \mathrm{P} 3= \\
\text { seed coating } \mathrm{CM} 8, \mathrm{P} 4=\text { biopriming } \mathrm{E} 1+\mathrm{F} 2 \mathrm{~B} 124 \text { jam, } \mathrm{P} 5=\text { biopriming } \mathrm{ST} 116 \mathrm{~B} 24 \text { jam, P6 = biopriming } \\
\mathrm{CM} 824 \text { jam, } \mathrm{P} 7=\text { biopriming } \mathrm{E} 1+\mathrm{F} 2 \mathrm{~B} 148 \text { jam, } \mathrm{P} 8=\text { biopriming ST116B } 48 \text { jam, } \mathrm{P} 9=\text { biopriming } \mathrm{CM} 848 \\
\text { jam, } \mathrm{P} 10=\text { priming dengan fungisida metalaksil. } \mathrm{P} 0, \mathrm{P} 1, \mathrm{P} 2, \mathrm{P} 3, \mathrm{P} 4, \mathrm{P} 5, \mathrm{P} 6, \mathrm{P} 10 \text { dikeringkan dalam laminar } \\
\text { air flow cabinet selama } 24 \text { jam, sedangkan } \mathrm{P} 7, \mathrm{P} 8, \mathrm{P} 9 \text { dikeringkan selama } 48 \text { jam. Angka yang diikuti huruf } \\
\text { yang sama pada kolom atau baris yang sama menunjukkan tidak berbeda nyata pada berdasaran DMRT taraf } \\
5 \% \text {. Huruf kecil ke samping (dalam satu baris) menunjukkan pengaruh periode simpan sedangkan huruf } \\
\text { kapital ke bawah (dalam satu kolom) menunjukkan pengaruh perlakuan benih. }\end{array}$} \\
\hline
\end{tabular}


Tabel 7. Pengaruh periode simpan dan perlakuan benih terhadap jumlah populasi rizobakteri di dalam jaringan benih

\begin{tabular}{lccccccc}
\hline Perlakuan & \multicolumn{7}{c}{ Periode Simpan (minggu) } \\
\cline { 2 - 8 } Benih & 0 & 4 & 8 & 12 & 16 & 20 & 24 \\
\hline P0 & - & - & - & - & - & - & - \\
P1 & $1.5 \times 10^{4}$ & $1.8 \times 10^{3}$ & $3.3 \times 10^{5}$ & $7.3 \times 10^{3}$ & $2.6 \times 10^{3}$ & $4.3 \times 10^{3}$ & $4.3 \times 10^{4}$ \\
P2 & $1.6 \times 10^{4}$ & $2.0 \times 10^{2}$ & $5.1 \times 10^{3}$ & $1.3 \times 10^{5}$ & $2.0 \times 10^{3}$ & $5.0 \times 10^{3}$ & $3.2 \times 10^{4}$ \\
P3 & $5.5 \times 10^{4}$ & $3.2 \times 10^{5}$ & $9.5 \times 10^{5}$ & $1.2 \times 10^{4}$ & $4.1 \times 10^{3}$ & $1.5 \times 10^{3}$ & $3.4 \times 10^{4}$ \\
P4 & $7.6 \times 10^{6}$ & $5.5 \times 10^{3}$ & $4.5 \times 10^{2}$ & $1.4 \times 10^{4}$ & $4.8 \times 10^{3}$ & $3.9 \times 10^{4}$ & $3.2 \times 10^{5}$ \\
P5 & $5.4 \times 10^{5}$ & $4.6 \times 10^{5}$ & $2.0 \times 10^{4}$ & $6.5 \times 10^{3}$ & $1.0 \times 10^{2}$ & $6.0 \times 10^{3}$ & $1.2 \times 10^{4}$ \\
P6 & $7.8 \times 10^{5}$ & $6.2 \times 10^{5}$ & $2.0 \times 10^{2}$ & $9.0 \times 10^{2}$ & $1.3 \times 10^{3}$ & $1.5 \times 10^{4}$ & $4.1 \times 10^{4}$ \\
P7 & $2.7 \times 10^{6}$ & $8.1 \times 10^{3}$ & $3.2 \times 10^{3}$ & $6.4 \times 10^{3}$ & $8.1 \times 10^{3}$ & $7.7 \times 10^{3}$ & $4.5 \times 10^{4}$ \\
P8 & $1.1 \times 10^{5}$ & $9.9 \times 10^{4}$ & $3.9 \times 10^{3}$ & $8.7 \times 10^{3}$ & $1.4 \times 10^{4}$ & $2.6 \times 10^{3}$ & $3.2 \times 10^{4}$ \\
P9 & $8.8 \times 10^{5}$ & $5.8 \times 10^{4}$ & $1.1 \times 10^{4}$ & $3.5 \times 10^{3}$ & $7.8 \times 10^{3}$ & $4.0 \times 10^{3}$ & $3.4 \times 10^{4}$ \\
P10 & - & - & - & - & - & - & - \\
\hline
\end{tabular}

Keterangan: $\mathrm{P} 0=$ kontrol tanpa diberi perlakuan rizobakteri, $\mathrm{P} 1=$ seed coating $\mathrm{E} 1+\mathrm{F} 2 \mathrm{~B} 1, \mathrm{P} 2=$ seed coating ST116B, P3 = seed coating CM8, P4 = biopriming E1 + F2B1 24 jam, P5 = biopriming ST116B 24 jam, P6 = biopriming CM8 24 jam, P7 = biopriming E1 + F2B1 48 jam, P8 = biopriming ST116B 48 jam, P9 = biopriming CM8 48 jam, P10 = priming dengan fungisida metalaksil. P0, P1, P2, P3, P4, P5, P6, P10 dikeringkan dalam laminar air flow cabinet selama 24 jam, sedangkan P7, P8, P9 dikeringkan selama 48 jam. Angka yang diikuti huruf yang sama pada kolom atau baris yang sama menunjukkan tidak berbeda nyata pada berdasaran DMRT taraf 5\%. Huruf kecil ke samping (dalam satu baris) menunjukkan pengaruh periode simpan sedangkan huruf kapital ke bawah (dalam satu kolom) menunjukkan pengaruh perlakuan benih. Tidak dilakukan analisis statistik. $(-)=$ tidak dilakukan pengujian.

Menurut Short (1981), salah satu gejala fitotoksik adalah pertumbuhan yang abnormal. Ilyas et al. (2015) melaporkan daya berkecambah benih cabai yang diberi perlakuan matriconditioning dengan Dithane M-45 $0.2 \%$ setelah 24 minggu disimpan mengalami penurunan dari $79 \%$ (0 minggu simpan) menjadi $55 \%$.

Populasi rizobakteri dalam jaringan benih pada perlakuan biopriming mengalami penurunan sejalan dengan periode simpan (Tabel 7). Perlakuan biopriming pada 0 minggu simpan memiliki populasi rizobakteri sebanyak $10^{5}-10^{7} \mathrm{cfu} \mathrm{g}^{-1}$ lalu menurun menjadi $10^{4} \mathrm{cfu} \mathrm{g}^{-1}$ setelah disimpan selama 24 minggu. Pada perlakuan seed coating, populasi rizobakteri $10^{4} \quad \mathrm{cfu}^{-1}$ dan pada periode simpan 24 minggu masih bertahan $10^{4} \mathrm{cfu} \mathrm{g}^{-1}$.

Jumlah populasi rizobakteri dipengaruhi oleh kemampuan bakteri dalam mempertahankan hidupnya, kondisi penyimpanan dan ketersediaan sumber nutrisi di dalam jaringan benih. Hasil penelitian Bardin dan Huang (2003) menunjukkan benih sugar beet yang dilapisi dengan agen biocontrol Erwinia rhapontici yang disimpan pada suhu $5{ }^{\circ} \mathrm{C}$ dapat menjaga viabilitas dan efektivitas biocontrol dalam melawan patogen setelah disimpan selama 8 minggu. Menurut O'Callaghan et al. (2006), kondisi penyimpanan dan kemasan dapat mempengaruhi viabilitas bakteri. Chen dan Lott (1991) menyatakan endosperma dan embrio pada benih cabai mengandung unsur $\mathrm{Mg}, \mathrm{K}, \mathrm{Cl}, \mathrm{Mn}, \mathrm{Na}, \mathrm{Ca}$, S dan Cu. Unsur-unsur tersebut dibutuhkan untuk sintesis protein, stabilisasi ribosom, membran sel, dinding sel, asam nukleat pada rizobakteri.

\section{KESIMPULAN}

Bahan terbaik yang efisien dan efektif untuk pelapisan benih (seed coating) cabai adalah natrium alginat $2.5 \%$. Perlakuan rizobakteri setelah penyimpanan 24 minggu mampu mempertahankan daya berkecambah (79.3-88.5\%), dibandingkan perlakuan benih dengan fungisida metalaksil (54.3\%). Pada akhir periode simpan, perlakuan biopriming dengan isolat CM8 selama 48 jam dan biopriming dengan isolat $\mathrm{E} 1+\mathrm{F} 2 \mathrm{~B} 1$ selama 24 jam memiliki indeks vigor paling tinggi. Populasi rizobakteri pada perlakuan biopriming mengalami penurunan dari $10^{5}$ $10^{7} \mathrm{cfu} \mathrm{g}^{-1}$ menjadi $10^{4} \mathrm{cfu} \mathrm{g}^{-1}$ setelah disimpan selama 24 minggu. Pada perlakuan seed coating, populasi rizobakteri tetap bertahan $10^{4} \mathrm{cfu} \mathrm{g}^{-1}$ setelah disimpan selama 24 minggu. 


\section{UCAPAN TERIMA KASIH}

Ucapan terima kasih disampaikan kepada Kemenristekdikti melalui program Penelitian Strategis Nasional Tahun Anggaran 2016 berjudul "Perlakuan Benih dengan Rizobakteri untuk Peningkatan Hasil dan Mutu Benih Cabai serta Pengendalian Busuk Phytophthora" yang diketuai Prof. Dr. Ir. Satriyas Ilyas, M.S., atas dana penelitian yang telah diberikan; Balai Penelitian Tanaman Rempah dan Obat (Balittro) atas fasilitas yang telah disediakan, dan kepada semua pihak yang telah membantu dalam menyelesaikan penelitian ini.

\section{DAFTAR PUSTAKA}

Anis, M., M.J. Zaki, S. Dawar. 2012. Development of a na-alginate-based bioformulation and its use in the management of charcoal rot of sunflower (Helianthus annus L.). Pakistan J. Bot. 44(3): 1167-1170.

Bardin, S.D., H.C. Huang. 2003. Efficacy of stickers for seed treatment with organic matter or microbial agents for the control of damping-off of sugar beet. Plant Pathology Bulletin. 12: 19-26.

Chen, P., J.N.A. Lott. 1992. Studies of Capsicum annum seeds: structure, storage reserves, and mineral nutrients. Can. J. Bot. 70: 518-529.

Copeland, L.O., M.B. McDonald. 2001. Principles of Seed Science and Technology. Kluwer Academic Publisher, United States of America.

Diniz, K.A., P.A. Silva, J.A. Oliveira, J.R.E. Evangelista. 2009. Sweet pepper seed responses to inoculation with microorganism and coating with micronutrients, amino acids and plant growth regulators. Sci. Agric. 66(3): 293-297.

Hapsari, R.T. 2013. Pemanfaatan Methylobacterium spp pada invigorasi dan teknik coating untuk meningkatkan vigor benih kedelai. [Tesis]. Sekolah
Pascasarjana Institut Pertanian Bogor. Bogor.

Ibrahim, A., S. Ilyas, D. Manohara. 2014. Perlakuan benih cabai (Capsicum annum L.) dengan rizobateri untuk mengendalikan Phytophthora capsici, meningkatkan vigor benih dan pertumbuhan tanaman. Bul. Agrohorti. 2(1): 22-30.

Ilyas, S., K.V. Asie, G.A.K Sutariati, Sudarsono. 2015. Biomatriconditioning or biopriming with biofungicide or biological agent applied on hot pepper (Capsicum annuum L.) seeds reduced seedborne Colletotrichum capsici and increased seed quality and yield. Acta Hortic. 1105(13): 89-96.

Justice, L.O., L.N. Bass. 2002. Prinsip dan Praktek Penyimpanan Benih. PT Rajagrafindo, Jakarta.

[Kementan] Kementrian Pertanian. 2014. Produktivitas cabai besar dan rawit menurut provinsi 2010-2014. http://www. pertanian.go.id/ap_pages/mod/datahorti. [19 September 2015].

Malabadi, R.B., J.V. Staden. 2005. Storability and germination of sodium alginate encapsulated somatic embryos derived from the vegetative shoot apices of mature Pinus patula trees. Plant Cell, Tissue and Organ Culture. 82(3): 259265.

Mushollaeni, W., E. Rusdiana. 2011. Karakterisasi natrium alginate dari Sargassum sp, Turbinaria sp, dan Padina sp. J. Teknol dan Industri Pangan. 22(1): 26-32.

McDonald, M.B. 2000. Seed priming. p. 287325. In M. Black, J.D. Bawley (eds). Seed Technology and its Biological Basis. CRC Pr.

O'Callaghan, M., J. Swaminathan, J. Lottmann, D.A. Wright, T.A. Jackson. 2006. Seed coating with biocontrol strain Pseudomonas fluorescens F113. 
New Zealand Plant Protection. 59: 8085.

Palupi, T., S. Ilyas, M. Machmud, E. Widajati. 2013. Coating benih dengan agen hayati untuk meningkatkan pertumbuhan dan hasil tanaman padi. J. Agron. Indonesia. 41(3): 175-180.

Rosadiah, F.N., S. Ilyas, D. Manohara. 2015. Perlakuan benih cabai (Capsicum аппиит 1.) dengan rizobakteri secara tunggal atau kombinasi dapat mengendalikan Phytophthora capsici dan meningkatkan pertumbuhan tanaman. J. Hort. Indonesia. 6(1): 1-10.

Sari, P.E. 2009. Pengaruh komposisi bahan pelapis dan Methylobacterium spp terhadap daya simpan benih dan vigor bibit kacang panjang (Vigna sinensis L.). [Skripsi]. Intitut Pertanian Bogor. Bogor.
Setiyowati, H., M. Surahman, S. Wiyono. 2007. Pengaruh seed coating dengan fungisida benomil dan tepung curcuma terhadap pathogen antraknosa terbawa benih dan viabilitas benih cabai besar (Capsicum anпиum L.). Bul. Agron. 35(3): 176-182.

Short, D.E. 1981. Phytotoxicity of pesticide to plants. Extension Entomologist University of Florida. 5(3): 4-5.

Syukur, M., R. Yunianti, R. Dermawan. 2012. Sukses Panen Cabai Tiap Hari. Penebar Swadaya, Jakarta.

Tefa, A. 2015. Pemanfaatan bakteri probiotik untuk menekan infeksi Colletotricum acutatum dan meningkatkan mutu benih cabai (Capsicum annuum L.) selama penyimpanan. [Tesis]. Sekolah Pascasarjana Institut Pertanian Bogor. Bogor. 